\title{
PENGARUH KEDALAMAN DAN JARAK DARI PANTAI TERHADAP KELIMPAHAN DAN POLA SEBARAN SAND DOLLAR DI PANTAI BARAKUDA PULAU KEMUJAN TAMAN NASIONAL KARIMUNJAWA
}

\author{
Adhe Nur Afian, Frida Purwanti, Supriharyono \\ Program Studi Manajemen Sumberdaya Perairan, Jurusan Perikanan \\ Fakultas Perikanan dan Ilmu Kelautan, Universitas Diponegoro
}

\begin{abstract}
ABSTRAK
Sand dollar merupakan kelas Echinoidea dari filum Echinodermata yang memiliki bentuk tubuh irregular yaitu bentuk tubuh bilateral dan pipih atau oval tanpa lengan, duri-duri menutup tubuh. Habitatnya di dasar perairan yang berpasir atau daerah berlumpur.Pantai Barakuda merupakan salah satu pantai di pulau Kemujan yang mempunyai daerah rataan pasir yang luas. Tujuan dari penelitian ini adalah untuk mengetahui komposisi jenis, kelimpahan dan pola sebaran sand dollar di Pantai Barakuda, untuk mengetahui variabel yang paling dominan antara kedalaman, jarak atau keduanya. Penelitian ini dilaksanakan pada bulan Juni 2013di Pantai Barakuda Pulau Kemujan Taman Nasional Karimunjawa, Kabupaten Jepara, Jawa Tengah.

Metode penelitian yang digunakan adalah survei lapangan yang bersifat deskriptif, pengambilan data dilakukan menggunakan line transek sepanjang $50 \mathrm{~m}$ dan kuadran transek 1x1 m. Pengamatan dilakukan dengan mengambil 2 stasiun, stasiun A yaitu dengan berjarak 20 meter dari tepi pantai dan stasiun B dengan berjarak berkisar 70 meter dari tepi pantai. Setiap stasiun ditarik 3 line transek yang sejajar dengan pantai sepanjang 50 meter, dengan jarak 10 meter antar line transek. Pengambilan sand dollar didalam kuadran dilakukan pada tiap meter dengan melihat jenis dan jumlahnya. Data yang diperoleh dianalisa menggunakan analisa regresi berganda.

Hasil penelitian menunjukkan di pantai Barakuda terdapat 14 corak jenis sand dollar (Laganum sp). Pengamatan dan perhitungan yang dilakukan, didapatkan jumlah Laganum $s p$ di stasiun A sebanyak 351 individu, sedangkan pada stasiun B sebanyak 779 individu. Kelimpahan relatifnya terbesar yang didapatkan di pantai Barakuda pada corak jenis corak 1 dan corak 5 sedangkan kelimpahan relatif terkecil adalah corak 12 dan corak 14. Pola sebarannya sebagian besar termasuk mengelompok (clumped) dan beberapa termasuk seragam (uniform). Kelimpahan dan pola sebaran dipengaruhi oleh kedalaman dan jarak.
\end{abstract}

Kata-kata kunci : Taman Nasional, pantai, kedalaman, jarak, kelimpahan, pola sebaran, sand dollar

\section{ABSTRACT}

Sand dollar belongs to the class of Echinoidea from the phylum of Echinoderm which have irregular body shape that is bilateral and flattenned or oval without arms, spines covered the body. Their habitat is on sandy or muddy bottom. Barracuda beach is one of the beaches at the Kemujan island that have vast areas of sand flats. The purpose of this research were to determinate species composition, abundance and distribution patterns of sand dollar at Barracuda beach, to know what is the most dominant variable between depth, distance or both. This study was conducted in June 2013 at Barracuda beach, Kemujan Island National Park Karimunjawa, Jepara, Central Java.

The method used was field survey, which data collected using line transect along of $50 \mathrm{~m}$ and quadrant transect $1 \times 1 \mathrm{~m}$. Observations were made by taking 2 stations with a distance of 20 meters from the shore as A station and 70 meters from the shore as B station. At each station were drawn 3 line parallel to the shore as long as 50 meters, with a distance between line transect is 10 meters.Sand dollars in the quadrant were observed in each meter on it's type and amount. The obtained data were analyzed using multiple regression analysis.

The results showed that at Barracuda beach there were 14 types of sand dollar species (Laganum $s p)$. From the observations and calculations done, get the number of Laganum sp species 351 individuals at station A, while at station B is 779 individuals. The greatest relative abundance found at Barracuda beach were type 1 and 5 whereas the smallest relative abundance were type 12 and 14 . Most distribution pattern belong to clustered (clumped) and some uniform. Abundance and distribution patterns were influenced by depth and distance .

Key words : National Park, beach, depth, range, abundance, distribution patterns, sand dollar 


\section{Pendahuluan}

Echinodermata adalah hewan laut kulitnya berduri, dibagi dalam lima kelas yaitu Holothuroidea, Asteroidea, Ophiuroidea, Echinoidea dan Crinoidea. Hewan-hewan ini umumnya banyak dijumpai di daerah pantai. Di Indonesia terdapat berbagai jenis Echinodermata dari ke lima kelas tersebut (Nontji, 2005). Menurut Aziz (1986) dalam Mu'arif (2009), kelas Echinodea yaitu sand dollar memiliki bentuk tubuh bilateral, pipih atau oval dan berwarna keabu-abuan. Kelompok organisme yang bersifat pasif dalam mencari makanan. Habitat sand dollar yang hidup di perairan pantai berpasir dengan membenamkan diri dalam substrat. Orang sering menemukan sand dollar terdampar di pantai dengan kerangka hewan mati, tidak ada duri pada kerangkanya dan sudah berwarna putih.

Taman Nasional menurut Undang-Undang No. 5 tahun 1990 tentang Konservasi Sumberdaya Alam Hayati dan Ekosistemnya didefinisikan sebagai kawasan pelestarian alam yang mempunyai ekosistem asli, dikelola dengan sistem zonasi yang dimanfaatkan untuk tujuan penelitian, ilmu pengetahuan, pendidikan, budidaya, pariwisata dan rekreasi, salah satunya adalah Taman Nasional Karimunjawa yang terletak di Laut Jawa dengan luas 110.117,30 Ha. Permasalahan yang menonjol dalam mengelola kawasan adalah perlindungan ekositem perairan laut salah satunya di Pulau Kemujan pada perairan pantai Barakuda yang termasuk dalam zona budidaya bahari (BTNKJ, 2008).

Perairan pantai Barakuda termasuk dalam perairan Pulau Kemujan Taman Nasional Karimunjawa, dimana pada perairan ini terdapat potensi sumberdaya alam yang melimpah, perairan ini merupakan kawasan wisata laut yang memiliki keindahan alamnya dan banyak dijumpai berbagai jenis hewan-hewan Echinodermata. Dalam perkembangannya banyak tumbuh aktifitas kegiatan manusia diantaranya pembuatan resort dan karamba, dengan demikian secara ekologis dapat merubah kondisi ketersediaan sand dollar di perairan tersebut.

Tujuan dari penelitian ini yaitu Untuk mengetahui komposisi dan kelimpahan jenis sand dollar yang terdapat di Pantai Barakuda, Pulau Kemujan. Untuk mengetahui pola sebaran sand dollar yang terdapat di Pantai Barakuda, Pulau Kemujan. Untuk mengetahui variabel yang paling dominan antara kedalaman, jarak atau keduanya terhadap kelimpahan dan pola sebaran sand dollar.

\section{Materi dan Metode Penelitian}

\section{A. Materi Penelitian}

Materi yang digunakan dalam penelitian ini adalah sand dollar dan parameter kualitas perairan yang terdapat di pantai Barakuda Pulau Kemujan, Taman Nasional Karimunjawa, Kabupaten Jepara, Jawa Tengah. Alat yang digunakan dalam penelitian ini yaitu Kuadran transek dengan ketelitian 1x1 m untuk membatasi daerah, line transek dengan ketelitian untuk menandai tempat sampling, masker snorkel untuk mencari dan melihat biota, refraktometer dengan ketelitian $1 \%$ untuk mengukur salinitas air, secchi disc dengan ketelitian untuk mengukur kecerahan dan kedalaman, termometer dengan ketelitian $1{ }^{\circ} \mathrm{C}$ untuk mengukur suhu udara dan air, bola arus dengan ketelitian $1 \mathrm{~cm}$ untuk mengukur kecepatan arus, stopwatch dengan ketelitian $0,1 \mathrm{~s}$ untuk mengukur waktu saat menghitung kecepatan arus, $\mathrm{pH}$ paper untuk mengukur derajat keasaman, alat tulis untuk memberi keterangan, Kertas label untuk memberi nama sampel, alkohol untuk mengawetkan sampel, Aquades untuk kalibrasi, komputer digunakan sebagai alat untuk mengolah data, kamera digital digunakan sebagai alat untuk mendokumentasikan kegiatan, iIdentifikasi menggunakan acuan Johnson (1915), Clark dan Rowe (1971), Mooi (1989), Britles dan Hughes (1989), Colin dan Arneson (1995), animal web dan Monterey Bay Aquarium.

\section{B. Metode Penelitian}

Metode yang digunakan dalam penelitian ini adalah metode survei lapangan yang bersifat deskriptif. Pada metode survei lapangan akan dilihat bagaimana kondisi lokasi penelitian. Metode yang bersifat deskriptif, merupakan sebuah penelitian yang dirancang untuk membantu membuat keputusan dalam menentukan, mengevaluasi dan memilih rangkaian tindakan yang harus diambil pada lokasi penelitian dan memiliki tujuan untuk menguji hipotesis

\section{Penentuan lokasi sampling}

Penentuan lokasi pengambilan sampel dengan observasi ke lapangan untuk mengetahui kondisi lokasi dan penentuan titik sampling di perairan pantai Barakuda pulau Kemujan, Taman Nasional Karimunjawa. Pemilihan lokasi sampling stasiun A dari tepi pantai sekitar 20 meter ke arah laut dengan lokasi dekat dermaga kapal dan karamba tukik kemudian ditarik garis transek sepanjang 50 meter sejajar dengan garis pantai, dimana dilakukan pengulangan line 2 dan 3 dengan masing-masing jarak 10 meter. Pemilihan lokasi sampling stasiun B bergeser ke kanan dari stasiun A dengan jarak dari lokasi dermaga dan karamba sekitar 70 meter ke arah laut, kemudian ditarik garis transek sepanjang 50 meter sejajar dengan garis pantai, dimana dilakukan pengulangan line 2 dan 3 dengan masing-masing jarak 10 meter, pada lokasi ini terkena paparan ombak. Penentuan lokasi juga melihat bagaimana kelimpahan jenis sand dollar.

\section{Pengambilan sampel lapangan}

Pengambilan sampel sand dollar dilakukan pada perairan pantai Barakuda dengan menggunakan kuadran 1 x 1 meter dan line transek sepanjang 50 meter, hal ini bertujuan agar hewan sand dollar yang 
diperoleh dapat mewakili keseluruhan dari daerah tersebut. Pengamatan sand dollar didalam kuadran pada tiap meter.Untuk lebih jelasnya lihat pada Gambar. Penghitungan dan pencatatan jenis serta jumlah sand dollar kemudian menganalisa data dan menarik kesimpulan dari hipotesis. Mengambil 1 corak jenis kemudian sampel diawetkan kedalam larutan alkohol untuk diidentifikasi.

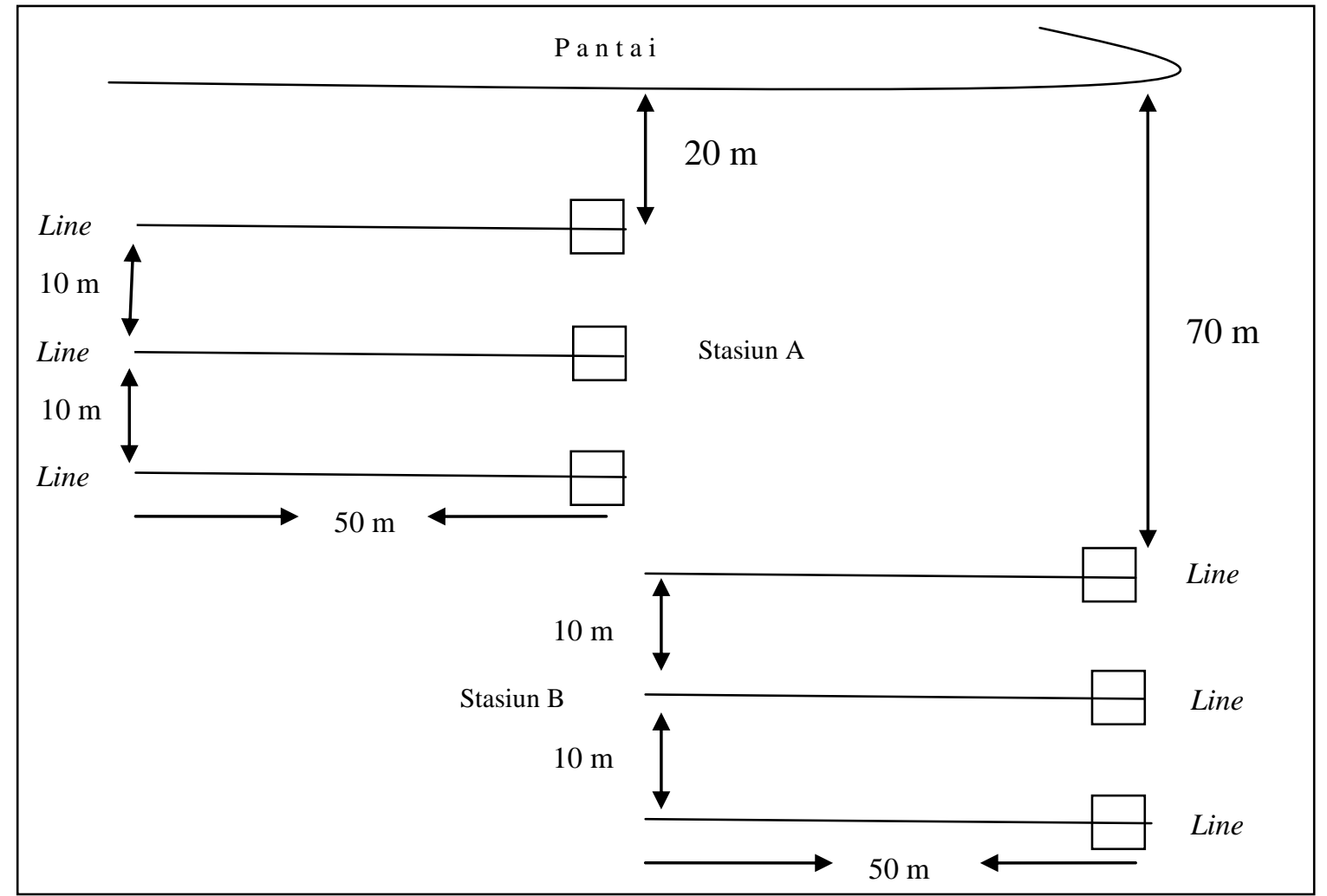

\section{Pengukuran Kualitas Perairan}

Gambar 1. Transek pada Lokasi Sampling sand dollar

Pengukuran parameter kualitas perairan antara lain salinitas, suhu, pH, kedalaman, kecerahan, kecepatan arus, serta mengamati dasar perairan. Kedalaman, kecerahan dan dasar substrat diukur pada setiap meter per line transek. Suhu dan kecepatan arus diukur per line transek. Sedangkan pengukuran $\mathrm{pH}$ dan salinitas per stasiun. Kemudian menghitung kelimpahan relatif serta menarik kesimpulan dari hipotesis.

\section{Analisa Data}

Densitas

Untuk mengukur jumlah individu yang diketemukan per area, dalam hal ini jumlah individu per $\mathrm{m}^{2}$. Densitas individu per area dihitung berdasarkan rumus (Misra, 1968 dalam Sulardiono, 2013) yaitu :

$$
\text { Densitas }=\frac{\text { jumlah individu spesies ke-i }}{\text { jumlah luas petakan dalam transek }}
$$

\section{Indeks Keanekaragaman dan Indeks Keseragaman}

Untuk menentukan keanekaragaman jenis digunakan Indeks Keanekaragaman (H') (Shannon dan Weaver, 1949 dalam Odum, 1971).

$$
\mathrm{H}^{\prime}=-\sum_{\mathrm{i}=\mathrm{s}}^{\mathrm{s}} \mathrm{Pi} \ln \mathrm{Pi}
$$

Keterangan :

H' = Indeks keanekaragaman

$\mathrm{Pi} \quad=$ Peluang spesies $\mathrm{i}$ dari total individu

$\mathrm{S} \quad=$ Jumlah spesies

indeks keanekaragaman (H') terdiri dari beberapa kriteria yaitu:

$\mathrm{H}^{\prime}>3,0 \rightarrow$ menunjukkan keanekaragaman sangat tinggi

$\mathrm{H}^{\prime} 1,6-3,0 \rightarrow$ menunjukkan keanekaragaman tinggi

$\mathrm{H}^{\prime} 1,0-1,5 \rightarrow$ menunjukkan keanekaragaman sedang

$\mathrm{H}^{\circ}<1 \quad \rightarrow$ menunjukkan keanekaragaman rendah

Sedangkan untuk menghitung keseragaman jenis dengan menggunakan rumus Indeks Evennes (Odum, 1971), yaitu : 
Dimana :

$$
\mathrm{e}=\frac{H^{\prime}}{H^{\prime} \max }
$$

e $\quad=$ Keseragaman jenis

$\mathrm{H}^{\prime} \max =\ln \mathrm{S}$ (jumlah jenis)

Kelimpahan Relatif dan Pola Sebaran

Untuk menentukan jumlah individu suatu spesies sand dollar terhadap jumlah total individu digunakan Kelimpahan Relatif (KR) (Odum, 1971).

$$
\mathrm{KR}=\mathrm{Pi} \times 100 \%
$$

Keterangan :
KR
: Kelimpahan relatif
$\mathrm{Pi} \quad$ : Peluang spesies i dari total individu

Analisa data untuk menghitung pola sebaran sand dollar pada kedalaman dan jarak pantai, dapat diketahui dengan melihat besarnya nilai mean (nilai rata-rata) dan nilai varian (standart error) (Odum, 1971). Untuk mencari besarnya nilai varian digunakan rumus :

$$
\mathrm{V}=\sqrt{\frac{2}{n-1}}
$$

Untuk mencari nilai mean $(\mathrm{m})$ digunakan rumus:

$$
\mathrm{m}=\frac{n}{N}
$$

dimana:

$\mathrm{v}=$ varian

$\mathrm{n}=$ jumlah individu

$\mathrm{m}=$ mean

$\mathrm{N}=$ jumlah seluruh sampel

Menurut Odum (1971), pola sebaran individu-individu organism di alam dibagi menjadi tiga bagian pola dasar yaitu random (acak), uniform (seragam), dan clumped (mengelompok) hasilnya akan mempunyai arti yaitu apabila:

$\mathrm{v}=\mathrm{m}$ berarti distribusinya random (acak)

$\mathrm{v}>\mathrm{m}$ berarti distribusinya clumped (mengelompok)

$\mathrm{v}<\mathrm{m}$ berarti distribusinya uniform (seragam)

Analisis Regresi Berganda

Analisa data untuk melihat hubungan kedalaman dan jarak dengan kelimpahan sand dollar dengan analisis regresi berganda. Data yang digunakan biasanya berskala interval atau rasio (Trihendradi, 2011).

Rumus regresi berganda sebagai berikut:

Keterangan:

$$
Y^{\prime}=a+b_{1} X_{1}+b_{2} X_{2}+\ldots+B_{n} X_{n}
$$

$\mathrm{Y}^{\prime}=$ Variabel dependen (kelimpahan)

$\mathrm{X}_{1}=$ Variabel independen (kedalaman)

$\mathrm{X}_{2}=$ Variabel independen (jarak)

a $=$ Konstanta (nilai $\mathrm{Y}^{\prime}$ apabila $\mathrm{X}=0$ )

$\mathrm{b}=$ Koefisien regresi (nilai peningkatan ataupun penurunan)

\section{Hasil dan Pembahasan Deskripsi lokasi}

Secara geografis Pantai Barakuda dapat dijelaskan yaitu terletak di Pulau Kemujan yang berbatasan dengan Pulau Karimunjawa Taman Nasional Karimunjawa. Stasiun A terletak pada 110 29'35,70" BT sampai $5^{\circ} 48^{\prime} 44,99^{\prime \prime}$ LS yang berdekatan dengan dermaga kapal dan stasiun B terletak pada $110^{\circ} 25^{\prime} 38,2^{\prime \prime}$ BT sampai $5^{\circ} 49^{\prime} 40,78^{\prime \prime}$ LS yang jauh dari tepi pantai. Pantai Barakuda di kelilingi oleh pulau-pulau kecil, yang terdapat penangkaran lumba-lumba, resort, penetasan telur penyu dan karamba pemeliharaan penyu serta dermaga berhentinya kapal-kapal nelayan. Menurut BTNKJ (2012), bahwa Pantai Barakuda termasuk dalam zona budidaya bahari (ZBb) dengan luas $1.370,729$ Ha. Zona budidaya bahari yaitu aktifitas yang tidak diperbolehkan adalah secara sengaja atau tidak sengaja mengambil, mengganggu atau memindahkan biota baik yang masih hidup atau yang mati beserta bagian - bagiannya.

\section{Komposisi Jenis dan Densitas}

Analisis komposisi jenis dan densitas sand dollar (Laganum sp) di pantai Barakuda dapat dilihat pada Tabel 1. Hasil analisis tersebut dapat memberikan informasi bahwa komposisi jenis maupun densitas (individu $/ \mathrm{m}^{2}$ ) jenis cenderung lebih tinggi di stasiun B. 
Tabel 1. Komposisi jenis dan densitas sand dollar (Laganum sp) di pantai Barakuda

\begin{tabular}{ccccccccccc}
\hline & \multicolumn{1}{c}{ Stasiun A } & \multicolumn{7}{c}{ Stasiun B } \\
\cline { 2 - 7 } Laganum sp & line & line & line & $\mathrm{Ni}$ & $\mathrm{D}$ & line & line & line & $\mathrm{Ni}$ & $\mathrm{D}$ \\
& 1 & 2 & 3 & & & 1 & 2 & 3 & & \\
\hline Corak 1 & 17 & 16 & 17 & 50 & 0,333 & 123 & 24 & 7 & 154 & 1,026 \\
Corak 2 & 12 & 9 & 13 & 34 & 0,226 & 83 & 8 & 4 & 95 & 0,633 \\
Corak 3 & 10 & 12 & 15 & 37 & 0,246 & 61 & 25 & 4 & 90 & 0,600 \\
Corak 4 & 4 & 15 & 13 & 32 & 0,213 & 51 & 16 & 6 & 73 & 0,486 \\
Corak 5 & 12 & 18 & 22 & 52 & 0,346 & 111 & 20 & 11 & 142 & 0,946 \\
Corak 6 & 2 & 10 & 14 & 26 & 0,173 & 25 & 15 & 0 & 40 & 0,266 \\
Corak 7 & 1 & 7 & 9 & 17 & 0,113 & 11 & 22 & 6 & 39 & 0,260 \\
Corak 8 & 0 & 7 & 7 & 14 & 0,933 & 11 & 6 & 0 & 17 & 0,113 \\
Corak 9 & 0 & 15 & 10 & 25 & 0,166 & 12 & 3 & 0 & 15 & 0,100 \\
Corak 10 & 3 & 21 & 9 & 33 & 0,220 & 31 & 17 & 0 & 48 & 0,320 \\
Corak 11 & 7 & 10 & 10 & 27 & 0,180 & 20 & 13 & 0 & 33 & 0,220 \\
Corak 12 & 0 & 0 & 4 & 4 & 0,026 & 9 & 1 & 2 & 12 & 0,080 \\
Corak 13 & 0 & 0 & 0 & 0 & 0 & 10 & 4 & 3 & 17 & 0,113 \\
Corak 14 & 0 & 0 & 0 & 0 & 0 & 0 & 3 & 1 & 4 & 0,026 \\
\hline$\Sigma$ & 68 & 140 & 143 & 351 & 3,175 & 558 & 177 & 44 & 779 & 5,189 \\
\hline
\end{tabular}

Sumber : Data Penelitian 2013

\section{Keanekaragaman dan Keseragaman}

Keanekaragaman dan keseragaman tersaji pada Tabel 2. Data indeks Keanekaragaman ( $\left.\mathrm{H}^{\prime}\right)$ dan Indeks Keseragaman (e) sand dollar di pantai Barakuda ada kecenderungan baik keanekaragaman maupun keseragaman jenis cenderung lebih tinggi di stasiun A yang dekat dari pantai daripada di stasiun B..

Tabel 2. Hasil data indeks Keanekaragaman (H') dan Indeks Keseragaman (e).

\begin{tabular}{ccc}
\hline \multirow{2}{*}{ Indeks } & \multicolumn{2}{c}{ Stasiun } \\
\cline { 2 - 3 } & $\mathrm{A}$ & $\mathrm{B}$ \\
\hline $\mathrm{H}^{\prime}$ & 2,319 & 2,036 \\
$\mathrm{e}$ & 0,933 & 0,771 \\
\hline
\end{tabular}

Sumber : Data Penelitian 2013

\section{Kelimpahan Relatif}

Kelimpahan relatif tersaji pada Tabel 3. Kelimpahan Relatif (KR) corak jenis sand dollar (Laganum $s p$ ) di pantai Barakuda yang tertinggi adalah corak 1 dan corak 5 sedangkan yang terendah adalah corak 12 dan corak 14.

Tabel 3. Kelimpahan Relatif (KR) jenis sand dollar (Laganum sp)

\begin{tabular}{|c|c|c|c|}
\hline \multirow{2}{*}{ No } & \multirow{2}{*}{ Laganum sp } & \multicolumn{2}{|c|}{ Stasiun } \\
\hline & & $\mathrm{A}(\%)$ & B (\%) \\
\hline 1. & Corak 1 & 14 & 20 \\
\hline 2. & Corak 2 & 10 & 12 \\
\hline 3. & Corak 3 & 12 & 11 \\
\hline 4. & Corak 4 & 9 & 10 \\
\hline 5. & Corak 5 & 15 & 18 \\
\hline 6. & Corak 6 & 7 & 5 \\
\hline 7. & Corak 7 & 5 & 5 \\
\hline 8. & Corak 8 & 4 & 2 \\
\hline 9. & Corak 9 & 7 & 2 \\
\hline 10. & Corak 10 & 9 & 6 \\
\hline 11. & Corak 11 & 7 & 4 \\
\hline 12. & Corak 12 & 1 & 2 \\
\hline 13. & Corak 13 & 0 & 2 \\
\hline 14. & Corak 14 & 0 & 1 \\
\hline
\end{tabular}

Sumber : Data Penelitian 2013

Pola Sebaran

Pola sebaran sand dollar (Laganum sp) tersaji pada Tabel 4. Data pola sebaran corak jenis sand dollar (Laganum sp) di pantai Barakuda.tiap corak berbeda, hampir semua corak termasuk pola sebaran 
mengelompok (clumped) tetapi ada yang termasuk dalam pola sebaran seragam (uniform) seperti pada corak 1 , corak 5 dan corak 10.

Tabel 4. Pola sebaran jenis sand dollar (Laganum sp) di pantai Barakuda.

\begin{tabular}{|c|c|c|c|c|}
\hline No & Laganum sp & Nilai varian $(\mathrm{V})$ & Nilai mean $(\mathrm{m})$ & Pola sebaran \\
\hline 1. & Corak 1 & 0,099 & 0,180 & uniform \\
\hline 2. & Corak 2 & 0,125 & 0,114 & clumped \\
\hline 3. & Corak 3 & 0,125 & 0,112 & clumped \\
\hline 4. & Corak 4 & 0,138 & 0,092 & clumped \\
\hline 5. & Corak 5 & 0,101 & 0,171 & uniform \\
\hline 6. & Corak 6 & 0,175 & 0,058 & clumped \\
\hline 7. & Corak 7 & 0,190 & 0,049 & clumped \\
\hline 8. & Corak 8 & 0,258 & 0,027 & clumped \\
\hline 9. & Corak 9 & 0,051 & 0,035 & clumped \\
\hline 10. & Corak 10 & 0,025 & 0,071 & uniform \\
\hline 11. & Corak 11 & 0,184 & 0,053 & clumped \\
\hline 12. & Corak 12 & 0,365 & 0,014 & clumped \\
\hline 13. & Corak 13 & 0,353 & 0,015 & clumped \\
\hline 14. & Corak 14 & 0,666 & 0,003 & clumped \\
\hline
\end{tabular}

Sumber : Data Penelitian 2013

\section{Kondisi Perairan}

Pantai Barakuda merupakan pantai dengan substrat dasar perairan berupa pasir putih dengan beberapa lamun, rumput laut, pecahan karang mati dan beberapa karang hidup. Kondisi perairan pantai Barakuda dapat dilihat pada Tabel 5.

Tabel 5. Kondisi perairan di Pantai Barakuda.

\begin{tabular}{|c|c|c|}
\hline $\begin{array}{l}\text { Parameter } \\
\text { Kualitas Air }\end{array}$ & Kisaran Hasil & Pustaka \\
\hline Suhu Air $\left({ }^{\circ} \mathrm{C}\right)$ & $28-32$ & 25-30 (Clark dan Rowe, 1971) \\
\hline Suhu udara $\left({ }^{\circ} \mathrm{C}\right)$ & $26-30$ & 0-40 (Nybakken, 1992) \\
\hline Salinitas $(\%)$ & $34-36$ & 34-36 (Aziz, 1986) \\
\hline $\mathrm{pH}$ & $7-7,1$ & 7,4-8,4 (Lerman, 1985) \\
\hline $\begin{array}{l}\text { Kecepatan Arus } \\
\left(\mathrm{m}^{\prime} / \mathrm{s}^{\prime}\right)\end{array}$ & $0,23-0,47$ & 0,083-1 (Nontji, 2005) \\
\hline Kecerahan $(\mathrm{cm})$ & $\approx$ (sampai dasar) & - \\
\hline Kedalaman (cm) & $55-158$ & 0-200 (Clark dan Rowe, 1971) \\
\hline Dasar Perairan & Pasir, lamun, pecahan karang, rumput laut, karang & Hawkes (1978) \\
\hline
\end{tabular}

Sumber : Data Penelitian 2013

Komposisi Jenis dan Kelimpahan

Hasil identifikasi menunjukkan terdapat empat belas corak jenis sand dollar dari spesies Laganum $s p$ yang hidup di Pantai Barakuda, tetapi pada stasiun A hanya terdapat dua belas corak jenis sand dollar (Laganum sp), sedangkan pada stasiun B terdapat empat belas corak jenis Laganum sp ditemukan. Jumlah nilai densitas per $\mathrm{m}^{2}$ sand dollar jenis Laganum sp berdasarkan Tabel 1 bahwa yang ditemukan di stasiun A sebanyak 3,175 individu $/ \mathrm{m}^{2}$, sedangkan pada stasiun B sebanyak 5,189 individu $/ \mathrm{m}^{2}$. Sand dollar yang didapatkan dalam penelitian ini sebagian besar ditemukan berada pada substrat dasar berpasir, dibandingkan pada substrat dasar lamun, rumput laut, pecahan karang,dan karang hidup. Menurut Nybakken (1992), sand dollar merupakan salah satu Echinodermata yang hidup didaerah pantai berpasir. Substrat dasar perairan yang berbeda mempengaruhi jumlah dan kelimpahan sand dollar yang ada di perairan tersebut. Kelimpahan relatif biota yang hidup lebih banyak dan tinggi, tidak ditemukan biota yang mati. Hal ini menunjukan bahwa keadaan perairan di pantai Barakuda baik sebagai habitat sand dollar khususnya jenis Laganum sp.

Komposisi dan kelimpahan sand dollar (Laganum sp) tiap stasiun A dan B berbeda-beda. Seperti Tabel 3 pada stasiun A, jumlah individu tertinggi pada jenis corak 5 dengan jumlah 52 individu kemudian corak 1 dengan jumlah 50 individu sampai yang terkecil adalah corak 12 sebanyak 4 individu. Berbeda 
dengan stasiun B, jumlah individu tertinggi pada jenis corak 1 dengan jumlah 154 individu kemudian corak 5 dengan jumlah 142 individu sampai yang terkecil adalah corak 14 sebanyak 4 individu. Stasiun B juga ditemukan corak 12 sebanyak 12 individu yang lebih banyak daripada di stasiun A. Stasiun A jenis corak 13 dan corak 14 tidak ditemukan karena kedua jenis tersebut ditemukan pada kedalaman tertentu dan ditemukan mengelompok dengan corak 11. Menurut Gregory (1892) bahwa jenis corak yang beraneka ragam banyak ditemukan secara mengelompok dan ditemukan hanya pada kedalaman tertentu dengan substrat yang lebih halus.

Kelimpahan relatif sand dollar berdasarkan pengaruh kedalaman dan jarak sangat bervariasi. Kelimpahan relatif tertinggi pada stasiun A adalah corak 5 dan kelimpahan relatif terendah adalah corak 12, sedangkan kelimpahan relatif tertinggi pada stasiun B adalah corak 1 dan kelimpahan relatif terendah adalah corak 14. Hal ini dikemukakan oleh Aziz (1987) bahwa sand dollar dengan spesies Laganum sp ditemukan melimpah pada kedalaman 1-2 meter. Kedalaman dan jarak berpengaruh pada kelimpahan dan pola sebaran sand dollar, sedikitnya kelimpahan sand dollar dengan kedalaman $65-81 \mathrm{~cm}$ pada jarak 20-40 m dari tepi pantai berjumlah 351 individu dibandingkan dengan stasiun B dengan kedalaman sekitar 110-158 cm pada jarak 70-90 m dari tepi pantai yang sangat melimpah dan beraneka ragam coraknya dengan total empat belas corak jenis Laganum sp berjumlah 779 individu. Menurut Dian, et al (2005) jumlah sand dollar jenis Laganum sp banyak ditemukan pada kedalaman 10-110 meter. Laganum sp menyebabkan melimpah adalah berdasarkan kedalaman. Pengambilan sampel sand dollar pada tiap stasiun menunjukan bahwa jenis Laganum sp memiliki jumlah tertinggi dari jenis lainnya yang secara keseluruhan mencapai 1130 individu.

Kelimpahan sand dollar (Laganum sp) di pantai Barakuda paling banyak ditemukan pada substrat dasar pasir. Pantai Barakuda terkenal dengan substrat dasar pasir yang luas sehingga substrat dasar pasir paling dominan dibandingkan dengan substrat dasar lainnya (lamun, rumput laut, pecahan karang dan karang). Persentasenya adalah pasir 79,67 \%, lamun 4,33\%, rumput laut 3,67 \%, pecahan karang 9,67\% dan karang hidup 2,67 \%. Hal ini disebabkan karena hewan ini hidup membenamkan diri dalam substrat (pasir halus atau lumpur berpasir) dan memperoleh makanannya dengan cara menelan pasir yang ada pada medium sekitarnya. Sand dollar merupakan salah satu organism yang bersifat deposit feeder yang hidup memakan sisa-sisa organisme yang terkandung dalam substrat. Hal ini sesuai dengan pernyataan Macginite (1968) dalam Supono dan Arbi (2012) yang bahwa sand dollar adalah organisme yang menyenangi substrat dasar perairan lumpur dan berpasir.

\section{Keanekaragaman dan Keseragaman}

Hasil pengamatan dan perhitungan yang dilakukan, didapatkan nilai indeks keanekaragaman (H') dan indeks keseragaman (e) tiap stasiun berbeda. Nilai indeks keanekaragaman pada stasiun A adalah 2,319 dan stasiun B adalah 2,306. Hal ini menunjukkan bahwa keanekaragaman sand dollar (Laganum sp) yang berada di Pantai Barakuda termasuk dalam kategori tinggi. Hal ini juga dinyatakan oleh Wilham (1975) dalam Suherman (2005) mengelompokkan tinggi indeks keanekaragaman (H') yaitu dengan nilai H'>2 yang berarti tinggi. Hal ini didasarkan pada jenis sand dollar (Laganum sp) yang ditemukan berjumlah total empat belas spesies. Jumlah ini menunjukkan bahwa habitat tempat hidup sand dollar dipengaruhi oleh kondisi fisik perairan tersebut, dimana didominasi substrat berpasir. Menurut Southwick (1976) bahwa nilai keanekaragaman yang besar akan didapatkan jika semua individu yang didapatkan pada contoh dari jenis yang berbeda-beda dan nilai keanekaragaman akan kecil jika semua individu yang didapatkan pada contoh hanya satu jenis saja.

Hasil perhitungan yang dilakukan, didapatkan nilai indeks keseragaman (e) tiap stasiun juga berbeda. Indeks keseragaman (e) pada stasiun A adalah 0,933 dan stasiun B adalah 0,771. Berdasarkan hasil tersebut diketahui indeks keseragaman (e) yang memiliki nilai > 0,6 yang berarti bahwa jenis sand dollar di Pantai Barakuda relatif tinggi. Hal ini dinyatakan oleh Nybakken (1992), bahwa indeks keseragaman merupakan gambaran secara sitematika tentang jumlah dan organisme yang menghuni suatu komunitas atau habitat tertentu. Nilai keseragaman dipengaruhi oleh kelimpahan setiap spesies. Semakin kecil indeks keseragaman suatu komunitas didominasi oleh satu spesies tertentu dan sebaliknya.

\section{Pola Sebaran}

Berdasarkan perhitungan yang dilakukan (Tabel 4) dapat dietahui bahwa pola distribusi dari sand dollar (Laganum sp) yang ditemukan di pantai Barakuda tiap spesies berbeda, dimana hampir semua spesies pola sebarannya termasuk mengelompok (clumped) tetapi ada yang termasuk pola penyebaran seragam (uniform) seperti pada jenis corak 1, corak 5, dan corak 10. Menurut Odum (1996) dalam Mulya (2000) bahwa pola sebarannya mengelompok atau bergerombol (clumped) merupakan pola yang paling umum dijumpai di alam. Hal ini dikarenakan sand dollar (Laganum sp) dalam menjalani hidupnya cenderung mencari tempat yang lebih sesuai untuk mendukung keberadaanya, sehingga akan berpengaruh pada pola sebarannya.

\section{Hubungan Kedalaman dan Jarak dari Pantai dengan Kelimpahan Sand dollar}

Analisa data stasistik menggunakan SPSS 16 untuk melihat pengaruh kedalaman dan jarak terhadap kelimpahan dan pola sebaran sand dollar (Laganum sp) di pantai Barakuda menggunakan analisis regresi berganda untuk mengetahui hubungan secara linear antara dua atau lebih variabel independen dengan 
variabel dependen (Trihendradi, 2011). Data didapatkan significance $F$ variabel kedalaman dan jarak bernilai 0,002 dan 0,000 menunjukkan bahwa probabilitas $\leq 0,05$, yang berarti $\mathrm{H}_{1}$ diterima, $\mathrm{H}_{0}$ ditolak. Hal ini menunjukkan bahwa variabel kedalaman dan jarak dapat menjelaskan hubungan dengan kelimpahan sand dollar (Laganum sp) di pantai Barakuda.

Parameter Kualitas Perairan

a. Suhu

Suhu air pada saat melakukan sampling di pantai Barakuda adalah sebesar $28-32^{\circ} \mathrm{C}$. Sedangkan suhu udara saat melakukan sampling di pantai Barakuda sebesar $26-30^{\circ} \mathrm{C}$. Ditinjau dari kisaran suhu air tersebut dapat diketahui bahwa suhu air memenuhi persyaratan bagi kelangsungan hidup sand dollar. Hal ini diperkuat oleh Page (2000), yang menyatakan bahwa organisme sand dollar dapat hidup baik di perairan pada kisaran suhu air antara $26-30^{\circ} \mathrm{C}$.

b. Salinitas

Salinitas pada lokasi sampling 34-36\% yang merupakan nilai salinitas yang sesuai bagi kehidupan sand dollar (Laganum sp) dan juga biota laut lainnya. Hal ini diperkuat oleh Romimohtarto (2007) bahwa suhu alami air laut berkisar antara suhu di bawah $0^{\circ} \mathrm{C}$ sampai $33^{\circ} \mathrm{C}$. Perubahan suhu dapat memberi pengaruh besar kepada sifat-sifat air laut lainnya dan kepada biota laut.

c. $\mathrm{pH}$ (Derajat keasaman)

Berdasarkan pengukuran $\mathrm{pH}$ saat penelitian didapat kisaran antara 7-7,1. Kisaran seperti ini masih stabil karena $\mathrm{pH}$ air laut umumnya bervariasi dari lokasi ke lokasi berkisar 6,8-8,5. Untuk kehidupan di laut, nilai $\mathrm{pH}$ yang konstan berfungsi pada setiap aktifitas (Lerman, 1986).

\section{d. Kecepatan Arus}

Kecepatan arus yang didapat di pantai Barakuda berkisar antara $0,23 \mathrm{~m} / \mathrm{s}$ sampai $0,47 \mathrm{~m} / \mathrm{s}$, sand dollar (Laganum sp) memiliki adaptasi morfologis dengan tubuh simetris radial yang terbagi menjadi 5 bagian. Gerakannya lambat dengan kaki pembuluh untuk mengatur tekanan air. Biasanya hewan ini bersembunyi di dalam substrat pasir. Menurut Hawkes (1978) dalam Mu'arif (2009), menyatakan bahwa secara umum kecepatan arus baik secara langsung atau tidak langsung mempengaruhi substrat dasar yang merupakan faktor yang menentukan komunitas hewan sand dollar.

e. Kedalaman

Pengukuran kedalaman dilakukan pada semua kuadran transek dengan hasil yang berkisar antara 55-158 cm. Kedalaman lokasi sampling di pantai Barakuda berubah-ubah karena dasar perairan tidak rata. Hal ini diperkuat oleh Aziz (1981) dalam Mu'arif (2009), bahwa spesies sand dollar ditemukan pada kedalaman antara 1-2 meter dengan catatan mengenai habitat, macam dasar, kedalaman dan zonasi digunakan untuk penggambaran sebaran lokal dari fauna yang bersangkutan.

f. Kecerahan

Kecerahan pada lokasi pengamatan tak terhingga dikarenakan substrat dasar masih tampak. Sinar matahari dapat menembus hingga ke dasar perairan. Menurut Nybakken (1992), menjelaskan bahwa air sangat kuat menyerap cahaya. Akibatnya, cahaya yang masuk ke air hanya dapat menembus sampai kedalaman tertentu, walaupun kedalaman ini bervariasi tetapi kenyataannya cukup dangkal.

\section{g. Substrat Dasar}

Substrat dasar perairan pada lokasi pengamatan berupa pasir, pecahan karang, karang hidup, rumput laut dan lamun, sedangkan sand dollar banyak ditemukan berada pada daerah substrat berpasir saat air surut. Menurut Hawkes (1978) dalam Mu'arif (2009), bahwa substrat dasar merupakan faktor yang berpengaruh langsung terhadap komposisi dan distribusi hewan benthos, disamping itu juga sebagai tempat hidup dan juga sebagai sumber makanan bagi sebagian besar hewan tersebut.

\section{Kesimpulan}

Berdasarkan hasil dan pembahasan dapat diambil kesimpulan sebagai berikut:

1. Komposisi jenis terdapat 14 corak jenis sand dollar (Laganum $s p$ ) yang ditemukan di Pantai Barakuda Pulau Kemujan. Pada stasiun A hanya 12 corak jenis Laganum sp dan pada stasiun B ada 14 corak jenis Laganum sp. Didapatkan nilai indeks keanekaragaman (H') pada stasiun A dan B adalah 2,319 dan 2,036. Nilai indeks keseragaman (e) sebesar 0,933 dan 0,771, hal ini menunjukkan keanekaragaman dan keseragaman tinggi

2. Pola sebaran sand dollar (Laganum sp) banyak ditemukan secara mengelompok (clumped) namun juga ada yang termasuk pola sebaran yang seragam (uniform) seperti pada corak 1, corak 5 dan corak 10 .

3. Kedalaman dan jarak dari pantai berpengaruh pada kelimpahan dan pola sebaran sand dollar (Laganum $s p$ ), sedikitnya kelimpahan dan pola sebaran sand dollar dengan kedalaman 65-81 cm dengan jarak 20$40 \mathrm{~m}$ dari tepi pantai dibandingkan dengan kedalaman berkisar 110-158 cm dengan jarak 70-90 $\mathrm{m}$ dari tepi pantai yang sangat melimpah dan beraneka ragam dengan total spesies empat belas corak jenis Laganum sp. Kelimpahan dan pola sebaran sand dollar (Laganum sp) dipengaruhi oleh variabel kedalaman dan jarak. 


\section{Ucapan Terima Kasih}

Ucapan terima kasih ditujukan kepada kepada Prof. Dr. Ir. Supriharyono, MS dan Dr. Ir. Frida Purwanti, MSc atas bimbingannya dalam penyusunan penelitian ini. Ucapan terima kasih ditujukan pula Kepala BTNKJ dan Bapak Jayadi yang telah membantu penulis selama kegiatan penelitian.

\section{Daftar Pustaka}

Aziz, A. 1987. Makanan dan Cara Makan berbagai Jenis Bulu Babi. Balai Penelitian Biologi Laut. Pusat Penelitian dan Pengembangan Oseanologi - LIPI, Jakarta.

BTNKJ. 2008. Data Base Taman Nasional Karimunjawa Tahun 2008. Semarang. 2012. Peta Zonasi Taman Nasional Karimunjawa. Semarang.

Britles, R.D, and R.N. Hughes. 1989. Soft-Sediment Marine Invertebrates of Southeast Asia and Australia: A Guide to Identification. Australian Institute of Marine Sciene, Townsville.

Clark, A.M, And F.W. Rowe. 1971. Monograph Of Shallow Water Indo-West Pacific Echinodermata. Trustees Of The British Museum (Natural History), London.

Colin, P.L and C. Arnelson. 1995. A Field Guide to the Marine Invertebrate Occuring and Tropical Pasific Coral Reefs, Seagrass Beds and Mangroves. Tropical Pasific Invertebrates. Coral Reef Press, California. Pp 259.

Dian, A, R. Hartati dan Ambariyanto. 2005. Identifikasi Sand dollar dan Karakteristik Habitatnya di Pulau Cemara Besar, Kepulauan Karimunjawa Jepara. FPIK UNDIP, Semarang.

Gregory, 1892. Further Additions to Australian fossil Echinoidea. P.433

Johnson, L.C. 1915. Mesozoic and Cenozoic Echinodermata of the United States. U.S. National Museum, p.162.

Lerman, M. 1985. Marine Biology: Environment Diversity and Ecology. The Benyamin Cummings Publishing Company. Inc. Menlo Park, California.

Mooi, R. 1989. Living and Fosil Genera of The Clypeasteroida (Echinoidea : Echinodermata) : An Ilustrated Key and Annotated Checklist, Smithsonian Institusion Press. Washington DC.

Mu'arif, A. 2009. Kelimpahan dan Distribusi Sand Dollar (Laganum sp) Pada Substrat Dasar yang Berbeda di Pulau Cemara Kecil Kepulauan Karimunjawa Jepara. Undip, Semarang.

Mulya, M.B. 2000. Kelimpahan dan Distribusi Kepiting Bakau serta Keterkaitannya dengan Karakteristik Biofisik Hutan Mangrove di Suaka Margasatwa Karang Gading dan Langkat Timur Laut Provinsi Sumatera Utara. Institut Pertanian Bogor, Bogor. [THESIS].

Nontji, A. 2005. Laut Nusantara. Djambatan, Jakarta.

Nybakken, J.1992. Biologi Laut Suatu Pendekatan Ekologis. Gramedia, Jakarta.

Odum, E.P. 1971. Fundamentals of Ecology. $3^{\text {rd }}$ Edition. 324-351. WB Saunders Co. Philadelphia and London.

1993. Dasar-dasar Ekologi. Terjemahan Tjahjono Samingan. Gadjah Mada University Press, Yogyakarta.

Page, C. 2000. Dollar Umum Pasir Diunduh 9 April 2000 di http:/octopus.gma.org/Tidings/sanddollar.html.

Romimohtarto, K dan S. Juwana. 2007. Biologi Laut. Djambatan, Jakarta.

Southwick, C.H. 1976. Ecology and the Quality of Our Environment Second Edition. D. Van Company, New York.

Suherman. 2005. Struktur Komunitas Zooplankton di Perairan Teluk Jakarta. Institut Pertanian Bogor, Bogor.

Sulardiono, B. 2013. Aspek Hidro-Oseanografi Habitat Teripang (Holothuroidea:Echinodermata) di Perairan Karimunjawa, Jawa Tengah. Buletin Oseanografi Marina April 2013. Vol.2, Semarang. Halaman 87-96

Supono, dan U.Y. Arbi. 2012. Kelimpahan dan Keragaman Echinodermata di Pulau Pari Kepulauan Seribu. UPT Loka Konservasi Biota Laut - LIPI Bitung, Sulawesi Utara.

Suwingyo, S., B. Widigdo, Y. Wardiatno, M. Krisanti. 2005. Avertebrata Air Jilid 2. Jakarta: Penebar Swadaya.

Trihendradi, C. 2011. Langkah Mudah Melakukan Analisis Statistik menggunakan SPSS 19. CV. ANDI, Yogyakarta.

http://www.animal-diversity.com. (Diakses pada bulan Juni 2013)

http://www.Monterey Bay Aquarium.com. (Diakses pada bulan Juni 2013) 